\title{
Homeostasis of chosen bioelements in organs of rats receiving lithium and/or selenium
}

\author{
Małgorzata Kiełczykowska • Irena Musik • Renata Żelazowska • Anna Lewandowska • \\ Jacek Kurzepa $\cdot$ Joanna Kocot
}

Received: 8 June 2016/ Accepted: 26 July 2016/Published online: 30 July 2016

(C) The Author(s) 2016. This article is published with open access at Springerlink.com

\begin{abstract}
Lithium is an essential trace element, widely used in medicine and its application is often long-term. Despite beneficial effects, its administration can lead to severe side effects including hyperparathyroidism, renal and thyroid disorders. The aim of the current study was to evaluate the influence of lithium and/or selenium treatment on magnesium, calcium and silicon levels in rats' organs as well as the possibility of using selenium as an adjuvant in lithium therapy. The study was performed on rats divided into four groups (six animals each): control-treated with saline; Li-treated with $\mathrm{Li}_{2} \mathrm{CO}_{3}$ (2.7 mg Li/kg b.w.); Se-treated with $\mathrm{Na}_{2} \mathrm{SeO}_{3} \cdot \mathrm{H}_{2} \mathrm{O}(0.5 \mathrm{mg} \mathrm{Se} / \mathrm{kg}$ b.w.); $\mathrm{Se}+\mathrm{Li}$-treated simultaneously with $\mathrm{Li}_{2} \mathrm{CO}_{3}$ and $\mathrm{Na}_{2} \mathrm{SeO}_{3} \cdot \mathrm{H}_{2} \mathrm{O}(2.7 \mathrm{mg} \mathrm{Li} / \mathrm{kg}$ b.w. and of $0.5 \mathrm{mg} \mathrm{Se} /$ $\mathrm{kg}$ b.w., respectively). The administration was performed in form of water solutions by stomach tube once a day for 3 weeks. In the organs (liver, kidney, brain, spleen, heart, lung and femoral muscle) the concentrations of magnesium, calcium and silicon were determined. Magnesium was increased in liver of $\mathrm{Se}$ and $\mathrm{Se}+\mathrm{Li}$ given rats. Lithium decreased tissue $\mathrm{Ca}$ and co-administration of selenium reversed this effect. Silicon was not affected by any treatment. The beneficial effect of selenium on disturbances of
\end{abstract}

M. Kiełczykowska · I. Musik · R. Żelazowska ·

A. Lewandowska $\cdot$ J. Kurzepa $\cdot$ J. Kocot $(\bowtie)$

Chair and Department of Medical Chemistry, Medical University of Lublin, Chodźki 4a, 20-093 Lublin, Poland

e-mail: joanna.kocot@umlub.pl calcium homeostasis let suggest that further research on selenium application as an adjuvant in lithium therapy is worth being performed.

Keywords Selenium $\cdot$ Lithium $\cdot$ Magnesium · Calcium $\cdot$ Silicon $\cdot$ Male rats

\section{Introduction}

Lithium, an essential trace element, is widely used in different fields of medicine. For many years it has been used mostly in psychiatry (Shalbuyeva et al. 2007; Młyniec et al. 2014). However, studies have revealed the possibility of its application in other cases e.g.: in therapy of thyroid diseases, neurodegenerative disorders or preventing nephrolithiasis (Camins et al. 2009; Zhang et al. 2009; Wallace 2014; Chouhan et al. 2016). Lithium chloride has been suggested to be effective in leukemia therapy ( $\mathrm{Li}$ et al. 2015). The application of lithium is connected with considerable problems since lithium shows beneficial action only within a strongly determined range (Młyniec et al. 2014). The exceeding of the safe threshold may be accompanied with severe side effects including hyperparathyroidism, renal and thyroid disorders (McKnight et al. 2012; Lehmann and Lee 2013; Albert et al. 2013; Shine et al. 2015).

Relationships between lithium intake and bioelements homeostasis have been reported (Shalbuyeva 
et al. 2007; Oliveira et al. 2014; Shine et al. 2015; Harari et al. 2016). It has been suggested that the neuroprotective effects of lithium may be connected with its effect on intracellular $\mathrm{Ca}^{2+}$ concentrations (Wallace 2014). Hypercalcaemia is connected with lithium administration, however, this issue has been reported not to be fully investigated yet (Albert et al. 2013). $\mathrm{Mg}^{2+}$ and $\mathrm{Li}^{+}$ions have been found to compete for binding-site of some enzymes (Dudev and Lim 2011). Our previous studies have revealed the effect of lithium treatment on silicon level in animal organs (Kiełczykowska et al. 2008).

The searching for protective agents against lithium action seems to be worth studying considering that its application in psychiatric patients is commonly longterm and irrespective of numerous side effects it is still recommended as a first-line maintenance treatment for bipolar disorder (Albert et al. 2013). Furthermore, the scientists have recently pointed that growing use of lithium may result in increased environmental contamination with this element (Tkatcheva et al. 2015). The risk for consumers resulting from the possible occurrence of lithium in drinking water is also suggested to be considered (Harari et al. 2016). As different bioelements showed protective properties against different harmful factors, we undertook the current study aiming at evaluation of the possible beneficial influence of selenium on calcium, magnesium and silicon in organs of rats exposed to lithium. Selenium-an important trace element-has already been studied in regard to its protective action against numerous factors, both chemical and physical, and the obtained results have been highly encouraging (Ghodbane et al. 2011; Hassanin et al. 2013; Jebur et al. 2014; Shen et al. 2016). An additional reason for this study was the fact that an organoselenium compound ebselen has been reported to show some lithium-mimetic properties what has made the authors suggest the possibility of future application of ebselen in bipolar disorder therapy (Masaki et al. 2016). An acknowledged inorganic supplement sodium selenite, still used in clinical practice (Savory et al. 2012; Manzanares et al. 2015) and as a supplement of animal food (Pavlović et al. 2010; Cun et al. 2015) was chosen, on account of its bioavailability.

The aim of the current study was to evaluate the influence of lithium treatment on magnesium, calcium and silicon levels in rats' organs as well as the effectiveness of selenium as an adjuvant in lithium therapy.

\section{Materials and methods}

Animals

The experiment was performed on adolescent male Wistar rats (24 animals, 130-160 g body weight). The animals had free access to standard feed and drinking water. The study was carried out according to statutory bioethical standards and approved by I Local Ethical Commission of Medical University of Lublin, acceptance no. $1 / 2013$.

\section{Experimental design}

After 3-day-acclimatization period the rats were divided randomly into four groups (six animals each): group I (control) - treated with saline; group II (Li) treated with lithium $\left(\right.$ as $\mathrm{Li}_{2} \mathrm{CO}_{3}$ ) at a dose of $2.7 \mathrm{mg}$ $\mathrm{Li} / \mathrm{kg}$ b.w.; group III (Se) - treated with selenium (as $\mathrm{Na}_{2} \mathrm{SeO}_{3} \cdot \mathrm{H}_{2} \mathrm{O}$ ) at a dose of $0.5 \mathrm{mg} \mathrm{Se} / \mathrm{kg} \mathrm{b.w.;} \mathrm{group}$ IV $(\mathrm{Se}+\mathrm{Li})$ - treated simultaneously with lithium $\left(\mathrm{Li}_{2} \mathrm{CO}_{3}\right)$ and selenium $\left(\mathrm{Na}_{2} \mathrm{SeO}_{3} \cdot \mathrm{H}_{2} \mathrm{O}\right)$ at a dose of $2.7 \mathrm{mg} \mathrm{Li} / \mathrm{kg}$ b.w. and of $0.5 \mathrm{mg} \mathrm{Se} / \mathrm{kg}$ b.w., respectively. The administration was performed in form of water solutions by stomach tube. The treatment was performed once a day, for a period of 3 weeks. Basing on the body mass of each animal, measured every day before administration, the appropriate amount of selenium and/or lithium solutions was calculated. In the end of the experiment the animals were sacrificed under thiopental narcosis and samples of tissues of liver, kidney, brain, spleen, heart, femoral muscle and lung were collected. Ten $\%(\mathrm{w} / \mathrm{v})$ tissue homogenates were prepared in $0.1 \mathrm{~mol} \mathrm{dm}{ }^{-3}$ Tris- $\mathrm{HCl}$ buffer, $\mathrm{pH}$ 7.4. Supernatants were obtained by centrifugation at $5000 \times g$ for $30 \mathrm{~min}$.

\section{Biochemical investigations}

In the prepared tissue supernatants the concentrations of magnesium, calcium and silicon were determined. Magnesium and calcium concentrations were assayed by colorimetric methods using diagnostic kits Liquick Cor-MG 60 and Liquick Cor-CALCIUM 120, respectively. The concentration of silicon was measured 
using the spectrophotometric method (Wielkoszyński 2000). The obtained values of the determined elements' concentrations were expressed in $\mu \mathrm{mol} \mathrm{g}{ }^{-1}$ of wet tissue. The assays were performed using spectrophotometer SPECORD M40 (Zeiss Jena).

\section{Statistics}

All statistical analyses were performed using STATISTICA program (version 10.0) The normality of data distribution was verified using Shapiro-Wilk test. The differences among the studied groups were analyzed using a one-way analysis of variance (ANOVA), followed by Tukey test (for normally distributed variables) or Kruskal-Wallis one way analysis of variance (for non-normally distributed variables). Values were considered significant with $\mathrm{p}<0.05$.

\section{Results}

In liver magnesium was significantly increased in animals treated by $\mathrm{Se}$ alone and $\mathrm{Li}+\mathrm{Se}$ versus both control and Li-alone groups. The other two elements showed no distinct differences among the studied groups. In kidney no influence of any treatment on the studied bioelements was observed. In brain $\mathrm{Mg}$ and $\mathrm{Si}$ were not affected by $\mathrm{Li}$ and/or Se treatment. In contrast, in case of calcium Li-treatment caused a significant decrease versus control. In Se alone given rats a well-marked $\mathrm{Ca}$ enhancement versus both control and Li-treatment was observed. Co-administration of $\mathrm{Li}$ and $\mathrm{Se}$ resulted in a significant increase versus both control and Li-treated groups, whereas compared to Se alone group a significant depletion was noted. All the presented above results were shown on Fig. 1.

Similarly as in brain, in spleen calcium was the only element whose homeostasis was affected. Li alone and Se alone significantly decreased its tissue concentration versus control. Co-administration of Se resulted in full restoration of $\mathrm{Ca}$ as in $\mathrm{Li}+\mathrm{Se}$ group a wellmarked increase versus Li- and Se-treatments concomitant with no difference compared to control was obtained. In heart homeostasis of the studied bioelements generally showed no disturbances caused by the used treatments, except for an $\mathrm{Mg}$ increase versus $\mathrm{Li}$ - group in $\mathrm{Li}+\mathrm{Se}$-given rats. All the presented above results were shown on Fig. 2.

In femoral muscle and lung tissues calcium was also the only element, influenced by any of the used treatments. In femoral muscle $\mathrm{Se}$ alone and $\mathrm{Li}$ alone caused a well-marked decrease versus control, whereas in case of $\mathrm{Li}+\mathrm{Se}$-group the insignificant depletion was observed. In lung only $\mathrm{Li}$ alone administration resulted in a significant $\mathrm{Ca}$ decrease versus control. All the presented above results were shown on Fig. 3.

\section{Discussion}

In the current study lithium did not affect magnesium in any studied organ. Selenium alone or co-administered with $\mathrm{Li}$ also changed $\mathrm{Mg}$ level in no studied organ, except for liver, where significant increase was observed. This effect could be beneficial in patients receiving different drugs, considering the detoxifying role of liver and the evidence of relationships between magnesium and selenium level and incidence of liver disturbances (Markiewicz-Górka et al. 2011; Nangliya et al. 2015). Our previous studies revealed that intraperitoneal selenium can increase magnesium in liver and this effect was found to show a distinct dependence on the used form as a selenoorganic compound enhanced liver $\mathrm{Mg}$ much more considerably compared to inorganic selenite (Musik et al. 2010). In contrast Sivrikaya et al. (2013) observed no effect of intraperitoneally given sodium selenite on liver $\mathrm{Mg}$ of rats. No effect of lithium on magnesium, observed in the present work, is also partially consistent with one of the previous experiments performed in our department where the similar Li doses given in drinking water caused no changes or increase in $\mathrm{Mg}$ in rats' organs (Kiełczykowska et al. 2007). LiCl provided with drinking water also resulted in no changes of magnesium in brain, liver, skeletal muscle and cardiac muscle of rats (Csutora et al. 2006). The lack of connections between these two elements was also found by Baltaci et al. (2014) who observed that enhancement of $\mathrm{Li}$ in bone of ovariectomized rats fed Zn-deficient diet was accompanied with no changes of bone magnesium. The lack of disturbances of $\mathrm{Mg}$ level in brain by any treatment used in the present experiment seems to be very important, given that magnesium is regarded as one of the most important elements 

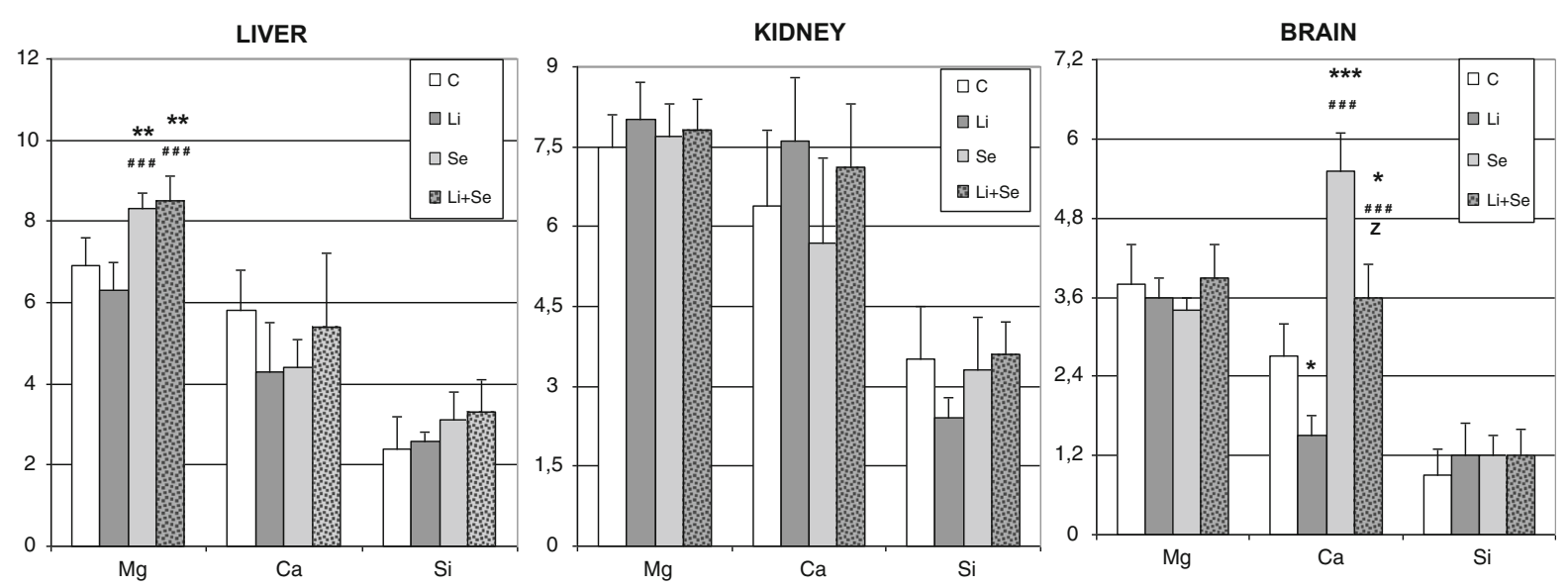

Fig. 1 Magnesium, calcium and silicon concentrations ( $\mu \mathrm{mol} \mathrm{g}{ }^{-1}$ of wet tissue) in organs of rats receiving lithium and/or selenium. ${ }^{*} \mathrm{p}<0.05$ versus control; ${ }^{*} \mathrm{p}<0.01$ versus control; ***p $<0.001$ versus control; ${ }^{\# \#} \mathrm{p}<0.001 \mathrm{Li}$-group; ${ }^{\mathrm{Z}} \mathrm{p}<0.001$ versus Se-group
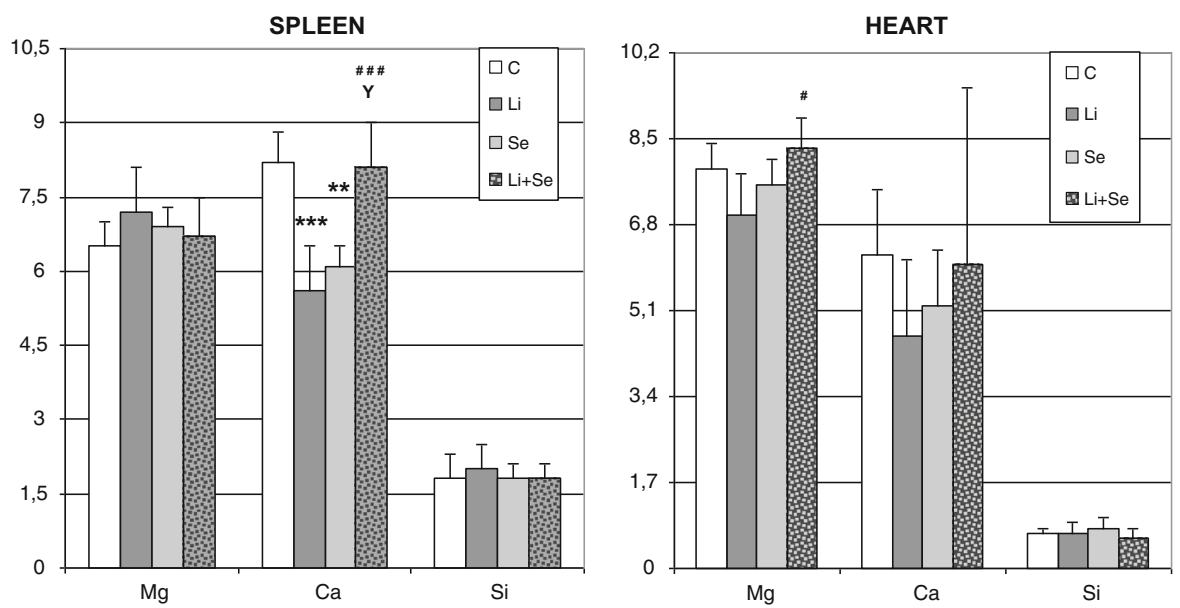

Fig. 2 Magnesium, calcium and silicon concentrations ( $\mu \mathrm{mol} \mathrm{g}{ }^{-1}$ of wet tissue) in organs of rats receiving lithium and/or selenium. ${ }_{* *} \mathrm{p}<0.01$ versus control; ***p $<0.001$ versus control; ${ }^{\#} \mathrm{p}<0.05 \mathrm{Li}$-group; ${ }^{\# \# \# ~}<0.001 \mathrm{Li}$-group; ${ }^{\mathrm{Y}} \mathrm{p}<0.01$ versus Se-group

for the central nervous system (Ghasemi et al. 2010). Magnesium is considered as a antagonist of $\mathrm{N}$-methylD-aspartate (NMDA) receptors and in Mg deficiency these receptors are hyperexcitable. Despite NMDA receptors are involved in several physiologic functions as excitatory synaptic transmission, neuronal plasticity and memory, their overstimulation leads to excitotoxicity resulting in neurons' death (de Baaij et al. 2015). Low serum Mg levels are associated with several neurological diseases such as migraine, depression, epilepsy and Alzheimer disease (AD) (Gupta et al. 1994; Gonulu et al. 2015; Gröber et al. 2015; Yary et al. 2016). In addition, the timedependence of lithium influence on brain magnesium was observed in fish exposed to Li. While no changes were observed at the beginning, after $72 \mathrm{~h}$ a decrease versus control was observed (Tkatcheva et al. 2015).

In the current study calcium was proved to be the most influenced element. It seems to be consistent with the hypothesis that lithium-induced hyperparathyroidism and hypercalcaemia can be connected with decrease in the intracellular calcium uptake (Kandil et al. 2011; Albert et al. 2013). The negative relationships between calcium and lithium were reported. In ovariectomized rats fed zinc-deficient diet markedly enhanced lithium in bone was accompanied with a significant calcium decrease (Baltaci et al. 2014). A case report study revealed that in a lithium-treated patient a decrease in dentin $\mathrm{Ca}$ was found (Eduardo et al. 2013). In a study performed on fish an interesting, 

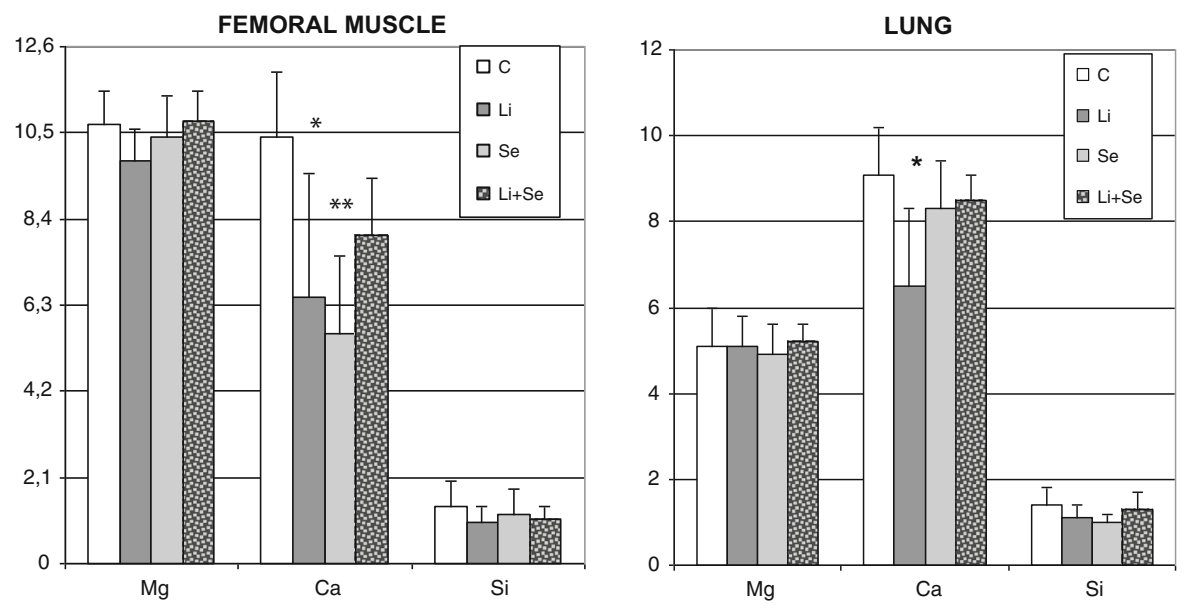

Fig. 3 Magnesium, calcium and silicon concentrations ( $\mu \mathrm{mol} \mathrm{g} \mathrm{g}^{-1}$ of wet tissue) in organs of rats receiving lithium and/or selenium. $* \mathrm{p}<0.05$ versus control; **p $<0.01$ versus control

time-dependent effect of lithium on brain calcium was found. No changes were observed at the beginning, after $24 \mathrm{~h}$ a decrease versus control was observed, after $72 \mathrm{~h}$ increase, and in the end (after $96 \mathrm{~h}$ ) no changes were observed again (Tkatcheva et al. 2015). The cytotoxicity of calcium has been recognized for about 35 years ago. A few theories explain the mechanism of excitotoxicity of $\mathrm{Ca}$, and all of them emphasize the higher than given threshold cytoplasmatic calcium level as an essential factor which enters the cell into the apoptotic pathway (Szydlowska et al. 2010). The elevated $\mathrm{Ca}$ level within the brain tissue in animals treated with Se can suggest the higher potential for excitotoxicity development, however, this observation needs further studies on cellular level.

Impairment of calcium homeostasis was also found in pregnant women exposed to $\mathrm{Li}$ in their drinking water and this effect was connected with vitamin D level disturbances (Harari et al. 2016). It is consistent with the fact that renal toxicity belongs to the main lithium side effects (Harrison et al. 2016). Other scientists also reported the disturbances of vitamin D in lithium-treated patients (van Melick et al. 2014).

No significant influence of lithium and/or selenium on silicon was found in the current study. Considering lithium's application in psychiatry and neurology it seems to be important as silicon is regarded as an essential element for brain (Santos-López et al. 2016). Previous animal study revealed the regional variations in silicon content within the brain which were independent of dietary silicon supplementation. However, supplementation of aluminum, which is potential factor for $\mathrm{AD}$ development, decreased the silicon content in selected brain regions (Carlise et al. 1987). In available literature data there is not too much information about relationships among these bioelements. One of our previous studies revealed that comparable doses of lithium, provided with drinking water, caused mostly no changes of Si in rats' organs. A slightly higher dose resulted in Si increase in liver and femoral muscle, whereas a lower one decrease in kidney. A wide spectrum of Li doses, studied in that experiment, did not alter brain silicon level (Kiełczykowska et al. 2008). The connections between selenium and silicon have been poorly investigated to date. However, it was suggested that a silicon influx transporter OSNIP2;1 is the first transporter of inorganic selenium (selenite form) in plants, microorganisms and animals (Zhao et al. 2010).

Open Access This article is distributed under the terms of the Creative Commons Attribution 4.0 International License (http:// creativecommons.org/licenses/by/4.0/), which permits unrestricted use, distribution, and reproduction in any medium, provided you give appropriate credit to the original author(s) and the source, provide a link to the Creative Commons license, and indicate if changes were made.

\section{References}

Albert U, De Cori D, Aguglia A, Barbaro F, Lanfranco F, Bogetto F, Maina G (2013) Lithium-associated hyperparathyroidism and hypercalcaemia: a case-control crosssectional study. J Affect Disord 151:786-790. doi:10.1016/ j.jad.2013.06.046 
Baltaci AK, Sunar F, Mogulkoc R, Acar M, Toy H (2014) The effect of zinc deficiency and zinc supplementation on element levels in the bone tissue of ovariectomized rats: histopathologic changes. Arch Physiol Biochem 120:80-85. doi:10.3109/13813455.2014.884141

Camins A, Crespo-Biel N, Junyent F, Verdaguer E, Canudas AM, Pallàs M (2009) Calpains as a target for therapy of neurodegenerative diseases: putative role of lithium. Curr Drug Metab 10:433-447

Carlisle EM, Curran MJ (1987) Effect of dietary silicon and aluminum on silicon and aluminum levels in rat brain. Alzheimer Dis Assoc Disord 1:83-89

Chouhan A, Abhyankar A, Basu S (2016) The feasibility of lowdose oral lithium therapy and its effect on thyroidal radioiodine uptake, retention, and hormonal parameters in various subcategories of hyperthyroid patients: a pilot study. Nucl Med Commun 37:74-78. doi:10.1097/MNM. 0000000000000414

Csutora P, Karsai A, Nagy T, Vas B, Kovács GL, Rideg O, Bogner P, Miseta A (2006) Lithium induces phosphoglucomutase activity in various tissues of rats and in bipolar patients. Int J Neuropsychopharmacol 9:613-619. doi:10. 1017/S146114570500622X

Cun GS, Robinson PH, Benes SE (2015) Bioavailability of selenium in 'Jose' tall wheatgrass (Thinopyrum ponticum var 'Jose') hay as a substitute for sodium selenite in the diets of dairy cattle. Sci Total Environ 518-519:159-167. doi:10.1016/j.scitotenv.2015.02.091

de Baaij JH, Hoenderop JG, Bindels RJ (2015) Magnesium in man: implications for health and disease. Physiol Rev 95:1-46. doi:10.1152/physrev.00012.2014

Dudev T, Lim C (2011) Competition between $\mathrm{Li}^{+}$and $\mathrm{Mg}^{2+}$ in metalloproteins Implications for lithium therapy. J Am Chem Soc 133:9506-9515. doi:10.1021/ja201985s

Eduardo Cde P, Simões A, de Freitas PM, Arana-Chavez VE, Nicolau J, Gentil V (2013) Dentin decalcification during lithium treatment: case report. Spec Care Dentist 33:91-95. doi: $10.1111 /$ scd. 12000

Ghasemi A, Saberi M, Ghasemi M, Shafaroodi H, Moezi L, Bahremand A, Montaser-Kouhsari L, Ziai P, Dehpour AR (2010) Administration of lithium and magnesium chloride inhibited tolerance to the anticonvulsant effect of morphine on pentylenetetrazole-induced seizures in mice. Epilepsy Behav 19:568-574. doi:10.1016/j.yebeh.2010.09.004

Ghodbane S, Amara S, Garrel C, Arnaud J, Ducros V, Favier A, Sakly M, Abdelmelek H (2011) Selenium supplementation ameliorates static magnetic field-induced disorders in antioxidant status in rat tissues. Environ Toxicol Pharmacol 31:100-106. doi:10.1016/j.etap.2010.09.010

Gonullu H, Gonullu E, Karadas S, Arslan M, Kalemci O, Aycan A, Sayin R, Demir H (2015) The levels of trace elements and heavy metals in patients with acute migraine headache. J Pak Med Assoc 65:694-697

Gröber U, Schmidt J, Kisters K (2015) Magnesium in prevention and therapy. Nutrients 7:8199-8226. doi:10.3390/nu7095388

Gupta SK, Manhas AS, Gupta VK, Bhatt R (1994) Serum magnesium levels in idiopathic epilepsy. J Assoc Phys India 42:456-457

Harari F, Åkesson A, Casimiro E, Lu Y, Vahter M (2016) Exposure to lithium through drinking water and calcium homeostasis during pregnancy: a longitudinal study. Environ Res 147:1-7. doi:10.1016/j.envres.2016.01.031

Harrison PJ, Cipriani A, Harmer CJ, Nobre AC, Saunders K, Goodwin GM, Geddes JR (2016) Innovative approaches to bipolar disorder and its treatment. Ann N Y Acad Sci 1366:76-89. doi:10.1111/nyas. 13048

Hassanin KM, Abd El-Kawi SH, Hashem KS (2013) The prospective protective effect of selenium nanoparticles against chromium-induced oxidative and cellular damage in rat thyroid. Int J Nanomed 8:1713-1720. doi:10.2147/ IJN.S42736

Jebur AB, Nasr HM, El-Demerdash FM (2014) Selenium modulates $\beta$-cyfluthrin-induced liver oxidative toxicity in rats. Environ Toxicol 29:1323-1329. doi:10.1002/tox. 21863

Kandil E, Dackiw AP, Alabbas H, Abdullah O, Tufaro AP, Tufano RP (2011) A profile of patients with hyperparathyroidism undergoing lithium therapy for affective psychiatric disorders. Head Neck 33:925-927. doi:10. 1002/hed.21563

Kiełczykowska M, Musik I, Hordyjewska A, Boguszewska A, Lewandowska A, Pasternak K (2007) Oral administration of lithium increases tissue magnesium contents but not plasma magnesium level in rats. Pharmacol Rep 59:291-295

Kiełczykowska M, Musik I, Pasternak K (2008) Relationships between silicon content and glutathione peroxidase activity in tissues of rats receiving lithium in drinking water. Biometals 21:53-59. doi:10.1007/s10534-007-9092-9

Lehmann SW, Lee J (2013) Lithium-associated hypercalcemia and hyperparathyroidism in the elderly: what do we know? J Affect Disord 146:151-157. doi:10.1016/j.jad.2012.08. 028

Li L, Song H, Zhong L, Yang R, Yang XQ, Jiang KL, Liu BZ (2015) Lithium chloride promotes apoptosis in human leukemia NB4 cells by inhibiting glycogen synthase kinase-3 Beta. Int J Med Sci 12:805-810. doi:10.7150/ ijms.12429.eCollection

Manzanares W, Langlois PL, Heyland DK (2015) Pharmaconutrition with selenium in critically ill patients: what do we know? Nutr Clin Pract 30:34-43. doi:10.1177/ 0884533614561794

Markiewicz-Górka I, Zawadzki M, Januszewska L, HombekUrban K, Pawlas K (2011) Influence of selenium and/or magnesium on alleviation alcohol induced oxidative stress in rats, normalization function of liver and changes in serum lipid parameters. Hum Exp Toxicol 30:1811-1827. doi:10.1177/0960327111401049

Masaki C, Sharpley AL, Godlewska BR, Berrington A, Hashimoto T, Singh N, Vasudevan SR, Emir UE, Churchill GC, Cowen PJ (2016) Effects of the potential lithium-mimetic, ebselen, on brain neurochemistry: a magnetic resonance spectroscopy study at 7 tesla. Psychopharmacol 233:1097-1104. doi:10.1007/s00213-015-4189-2

McKnight RF, Adida M, Budge K, Stockton S, Goodwin GM, Geddes JR (2012) Lithium toxicity profile: a systematic review and meta-analysis. Lancet 379:721-728. doi:10. 1016/S0140-6736(11)61516-X

Młyniec K, Davies CL, de Agüero Sánchez IG, Pytka K, Budziszewska B, Nowak G (2014) Essential elements in 
depression and anxiety Part I. Pharmacol Rep 66:534-544. doi:10.1016/j.pharep.2014.03.001

Musik I, Kiełczykowska M, Hordyjewska A, Pasternak K (2010) Influence of the administration of selenium compounds on tissue magnesium concentration in rats. J Elementol 15:536-547

Nangliya V, Sharma A, Yadav D, Sunder S, Nijhawan S, Mishra S (2015) Study of trace elements in liver cirrhosis patients and their role in prognosis of disease. Biol Trace Elem Res 165:35-40. doi:10.1007/s12011-015-0237-3

Oliveira TC, Campos Neto IA, Aguiar-Oliveira MH, Pereira Fde A (2014) Evaluation of parathyroid function and mineral metabolism in psychiatric patients using lithium salts. Arq Bras Endocrinol Metabol 58:619-624. doi:10.1590/00042730000002983

Pavlović Z, Miletić I, Jokić Ž, Pavlovski Z, Škrbić Z, Šobajić S (2010) The effect of level and source of dietary selenium supplementation on eggshell quality. Biol Trace Elem Res 133:197-202. doi:10.1007/s12011-009-8422-x

Santos-López JA, Garcimartín A, Merino P, López-Oliva ME, Bastida S, Benedí J, Sánchez-Muniz FJ (2016) Effects of silicon vs. hydroxytyrosol-enriched restructured pork on liver oxidation status of aged rats fed high-saturated/highcholesterol diets. PLoS One 11:e0147469. doi:10.1371/ journal.pone.0147469.eCollection

Savory LA, Kerr CJ, Whiting P, Finer N, McEneny J, Ashton T (2012) Selenium supplementation and exercise: effect on oxidant stress in overweight adults. Obesity (Silver Spring) 20:794-801. doi:10.1038/oby.2011.83

Shalbuyeva N, Brustovetsky T, Brustovetsky N (2007) Lithium desensitizes brain mitochondria to calcium, antagonizes permeability transition, and diminishes cytochrome C release. J Biol Chem 282:18057-18068. doi:10.1074/jbc. M702134200

Shen W, Chen J, Yin J, Wang SL (2016) Selenium protects reproductive system and foetus development in a rat model of gestational lead exposure. Eur Rev Med Pharmacol Sci 20:773-780

Shine B, McKnight RF, Leaver L, Geddes JR (2015) Long-term effects of lithium on renal, thyroid, and parathyroid function: a retrospective analysis of laboratory data. Lancet 38:461-468. doi:10.1016/S0140-6736(14)61842-0

Sivrikaya A, Akil M, Bicer M, Kilic M, Baltaci AK, Mogulkoc R (2013) The effect of selenium supplementation on elements distribution in liver of rats subject to strenuous swimming. Bratisl Lek Listy 114:12-14. doi:10.4149/ BLL_2013_003

Szydlowska K, Tymianski M (2010) Calcium, ischemia and excitotoxicity. Cell Calcium 47(2):122-129. doi:10.1016/j. ceca.2010.01.003

Tkatcheva V, Poirier D, Chong-Kit R, Furdui VI, Burr C, Leger R, Parmar J, Switzer T, Maedler S, Reiner EJ, Sherry JP, Simmons DB (2015) Lithium an emerging contaminant: bioavailability, effects on protein expression, and homeostasis disruption in short-term exposure of rainbow trout. Aquat Toxicol 161:85-93. doi:10.1016/j.aquatox.2015.01. 030

van Melick EJ, Wilting I, Ziere G, Kok RM, Egberts TC (2014) The influence of lithium on calcium homeostasis in older patients in daily clinical practice. Int J Geriatr Psychiatry 29:594-601. doi:10.1002/gps.4041

Wallace J (2014) Calcium dysregulation, and lithium treatment to forestall Alzheimer's disease - a merging of hypotheses. Cell Calcium 55:175-181. doi:10.1016/j.ceca.2014.02.005

Wielkoszyński T (2000) Modified spectrophotometric method of silicon determination in biological material. Diagn Lab 36:377-385 (In Polish)

Yary T, Lehto SM, Tolmunen T, Tuomainen TP, Kauhanen J, Voutilainen S, Ruusunen A (2016) Dietary magnesium intake and the incidence of depression: a 20 year follow-up study. J Affect Disord 193:94-98. doi:10.1016/j.jad.2015. 12.056

Zhang X, Aggarwal P, Li X, Oakman C, Wang Z, Rodriguez R (2009) The role of lithium carbonate and lithium citrate in regulating urinary citrate level and preventing nephrolithiasis. Int J Biomed Sci 5:215-222

Zhao XQ, Mitani N, Yamaji N, Shen RF, Ma JF (2010) Involvement of silicon influx transporter OsNIP2;1 in selenite uptake in rice. Plant Physiol 153:1871-1877. doi:10.1104/pp.110.157867 